APARTMENT STORIES 



\title{
APARTMENT STORIES
}

\author{
City and Home in Nineteenth-Century \\ Paris and London
}

SHARON MARCUS

University of California Press

Berkeley Los Angeles London 
University of California Press

Berkeley and Los Angeles, California

University of California Press, Ltd.

London, England

(C) 1999 by

The Regents of the University of California

Library of Congress Cataloging-in-Publication Data

Marcus, Sharon, I966-

Apartment stories : city and home in nineteenth-century Paris and London /

Sharon Marcus.

p. $\mathrm{cm}$.

Includes bibliographical references and index.

ISBN 0-520-208 52-8. — ISBN 0-520-2 I 726-8 (pbk.)

I. Apartment houses-Social aspects-

France-Paris-History-19th century.

2. Apartment houses-Social aspects-

England-London-History-19th century.

3. Personal space-England-London-

History-Igth century. 4. Paris (France)-

Social conditions - I9th century. 5. London

(England)-Social conditions-r 19 th century.

6. Paris (France)-Social life and customs-

19th century. 7. London (England)-Social life

and customs - igth century. 8. Paris (France)-

Intellectual life- 19 th century. 9. London

(England)-Intellectual life-rgth century.

I. Title.

HD7287.6.F82P375 1999

$307.3^{\prime} 36-\mathrm{dc} 2 \mathrm{I}$

$98-40597$

Printed in the United States of America

$\begin{array}{lllllllll}9 & 8 & 7 & 6 & 5 & 4 & 3 & 2 & \text { I }\end{array}$

The paper used in this publication meets the minimum requirements of American National Standards for Information Sciences-Permanence of Paper for Printed Library Materials, ANSI Z39.48-I984. 